\title{
GBA variants in REM sleep behavior disorder
}

\section{A multicenter study}

Lynne Krohn, MSc, Jennifer A. Ruskey, MSc, Uladzislau Rudakou, BSc, Etienne Leveille, Farnaz Asayesh, MSc, Michele T.M. Hu, MBBS, FRCP, PhD, Isabelle Arnulf, MD, PhD, Yves Dauvilliers, MD, PhD, Birgit Högl, MD, Ambra Stefani, MD, Christelle Charley Monaca, MD, PhD, Beatriz Abril, MD, Giuseppe Plazzi, MD, Elena Antelmi, MD, PhD, Luigi Ferini-Strambi, MD, Anna Heidbreder, MD, Bradley F. Boeve, MD, Alberto J. Espay, MD, MSc, Valérie Cochen De Cock, MD, PhD, Brit Mollenhauer, MD, Friederike Sixel-Döring, MD, Claudia Trenkwalder, MD, Karel Sonka, MD, David Kemlink, MD, PhD, Michela Figorilli, MD, PhD, Monica Puligheddu, MD, PhD, Femke Dijkstra, MD, Mineke Viaene, MD, PhD, Wolfgang Oertel, MD, Marco Toffoli, MD, Gian Luigi Gigli, MD, Mariarosaria Valente, MD, Jean-François Gagnon, PhD, Alex Desautels, MD, PhD, Jacques Y. Montplaisir, MD, PhD, Ronald B. Postuma, MD, MSc, Guy A. Rouleau, MD, PhD, FRCPC, and Ziv Gan-Or, MD, PhD

Neurology ${ }^{\circledR}$ 2020;95:e1008-e1016. doi:10.1212/WNL.0000000000010042

\section{Abstract}

\section{Objective}

To study the role of GBA variants in the risk for isolated REM sleep behavior disorder (iRBD) and conversion to overt neurodegeneration.

\section{Methods}

A total of 4,147 individuals were included: 1,061 patients with iRBD and 3,086 controls. GBA was fully sequenced using molecular inversion probes and Sanger sequencing. We analyzed the effects of GBA variants on the risk of iRBD, age at onset (AAO), and conversion rates.

\section{Results}

GBA variants were found in $9.5 \%$ of patients with iRBD compared to $4.1 \%$ of controls (odds ratio, 2.45 ; $95 \%$ confidence interval $\left.[\mathrm{CI}], 1.87-3.22 ; p=1 \times 10^{-10}\right)$. The estimated OR for mild p.N370S variant carriers was $3.69\left(95 \% \mathrm{CI}, 1.90-7.14 ; p=3.5 \times 10^{-5}\right)$, while for severe variant carriers it was $17.55(95 \%$ CI, $2.11-145.9 ; p=0.0015)$. Carriers of severe GBA variants had an average AAO of 52.8 years, $7-8$ years earlier than those with mild variants or noncarriers $(p=0.029)$. Of the GBA variant carriers with available data, $52.5 \%$ had converted, compared to $35.6 \%$ of noncarriers $(p=0.011)$, with a trend for faster conversion among severe GBA variant carriers. However, the results on AAO and conversion were based on small numbers and should be interpreted with caution.

\section{Conclusions}

GBA variants robustly and differentially increase the risk of iRBD. The rate of conversion to neurodegeneration is also increased and may be faster among severe $G B A$ variant carriers, although confirmation will be required in larger samples. Screening for RBD in healthy carriers of GBA variants should be studied as a potential way to identify GBA variant carriers who will develop a synucleinopathy in the future.

\author{
Correspondence \\ Dr. Gan-Or \\ ziv.gan-or@mcgill.ca
}

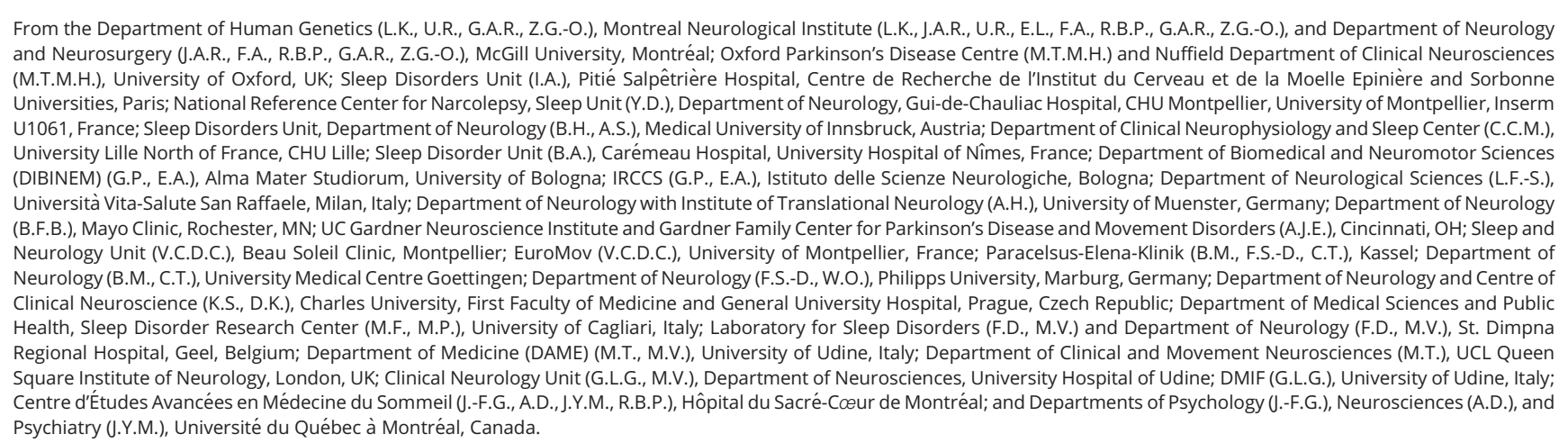

Go to Neurology.org/N for full disclosures. Funding information and disclosures deemed relevant by the authors, if any, are provided at the end of the article.

This is an open access article distributed under the terms of the Creative Commons Attribution License 4.0 (CC BY), which permits unrestricted use, distribution, and reproduction in any medium, provided the original work is properly cited. 


\section{Glossary}

AAO = age at onset $; \mathbf{C I}=$ confidence interval; $\mathbf{D L B}=$ dementia with Lewy bodies; GCase $=$ glucocerebrosidase $; \mathbf{G D}=$ Gaucher disease; GWAS = genome-wide association study; iRBD = isolated REM sleep behavior disorder; MIP = molecular inversion probe; $\mathbf{M S A}=$ multiple system atrophy; $\mathbf{N G S}=$ next-generation sequencing; $\mathbf{O R}=$ odds ratio; $\mathbf{P D}=$ Parkinson disease; $\mathbf{p R B D}=$ probable REM sleep behavior disorder; RBD = REM sleep behavior disorder.

Isolated REM sleep behavior disorder (iRBD) can be considered a prodromal synucleinopathy, because $>80 \%$ of patients with iRBD will eventually convert to an overt neurodegenerative syndrome associated with $\alpha$-synuclein accumulation-Parkinson disease (PD), dementia with Lewy bodies (DLB), or multiple system atrophy $(\mathrm{MSA})^{1}$ - with a conversion rate of about $6 \%$ a year. ${ }^{2}$ For unknown reasons, while some patients with iRBD convert rapidly, others can remain free from parkinsonism or dementia for decades. 3 ,

Variants in the gene encoding for the lysosomal enzyme glucocerebrosidase, $G B A$, are strong and relatively common risk factors for $\mathrm{PD}^{5,6}$ and $\mathrm{DLB},{ }^{7}$ yet their role in MSA is unclear. $^{8-10}$ Patients with PD who carry GBA variants, as a group, tend to have higher rates of nonmotor symptoms, including REM sleep behavior disorder (RBD), cognitive impairment, hyposmia, and autonomic dysfunction. ${ }^{11}$ GBA variants can be classified as severe or mild based on the type of Gaucher disease (GD) associated with the variant. ${ }^{12}$ Accordingly, patients with severe GBA variants have a higher risk for PD, an earlier average age at onset (AAO), ${ }^{5}$ and faster cognitive decline $\mathrm{e}^{13,14}$ compared to patients with $\mathrm{PD}$ with mild or no $G B A$ variants.

Few studies with small sample size have examined the role of GBA in iRBD, including studies of $69,{ }^{15} 171,{ }^{16}$ and 265 patients with $\mathrm{iRBD},{ }^{15}$ all supporting an association between $G B A$ variants and iRBD but with different risk estimates. It has been shown that in PD cohorts with available data on probable RBD ( $\mathrm{pRBD}$ ), GBA variants are more frequent in the group with $\mathrm{pRBD} .{ }^{15}$ However, there are no accurate estimates of the risk of iRBD among GBA variant carriers and there have been no studies separately analyzing severe and mild $G B A$ variants. It is not clear whether $G B A$ variants affect the rate of conversion from iRBD to overt synucleinopathies, as only 2 small sample size studies with contradicting results examined this hypothesis. In one, there was no association with the rate of conversion in 8 GBA variant carriers with $\mathrm{iRBD}^{16}$; in the other, a faster conversion was shown for 13 GBA variant carriers with iRBD compared to noncarriers. ${ }^{17}$

In this study, we analyzed GBA variants in a large, multicenter study including 1,061 patients with $\mathrm{RBBD}$, more than double the sample than all previous studies combined, and 3,086 controls, all of European origin. We further examined the effects of severe vs mild GBA variants on risk of iRBD, reported $A A O$ of $\mathrm{iRBD}$, and the potential effects on conversion from $\mathrm{iRBD}$ to an overt neurodegenerative disease.

\section{Methods}

\section{Population}

The patient population included 1,061 individuals diagnosed with $\mathrm{iRBD}$ with video-polysomnography according to the International Classification of Sleep Disorders, version 2 or 3 criteria. ${ }^{18}$ The recruiting centers and the number of patients from each center are detailed in table 1. Additional data were available for subsets of samples, including reported AAO of RBD ( $n=594)$, age at diagnosis of iRBD $(n=599)$, eventual phenoconversion to an overt neurodegenerative disease (data available for $\mathrm{n}=584$, converted $\mathrm{n}=218$ ), and rate of phenoconversion $(\mathrm{n}=217)$. The average follow-up period for GBA carriers was 4.8 years and for noncarriers it was 4.1 years $(p=0.22)$.

The data on these variables were collected in 2018. The control population included a total of 3,086 individuals, comprised of 1,317 in-house controls of European origin (confirmed by principal component analysis using available genome-wide association study [GWAS] data compared to data from HapMap v.3 and hg19/GRCh37) and an additional 1,769 previously published European controls in which GBA was fully sequenced and all the variants were reported (table e-1 details these controls and the reported GBA variants in each of the articles; github.com/gan-orlab/GBA_RBD/). The in-house controls had a mean age of $46.5 \pm 15.0$ years and included $46.6 \%$ men, compared to $60.5 \pm 9.9$ and $81 \%$ men in the patients, therefore when analyzing these populations, adjustment for age and sex was performed (see Statistical analysis and Results).

\section{GBA sequencing and classification of GBA variants}

GBA was fully sequenced as described previously ${ }^{19}$ and the full protocol is available upon request. In brief, we designed molecular inversion probes (MIPs) targeting the coding sequence of $G B A$ and performed next-generation sequencing (NGS) post capture. Alignment, variant calling, and annotations were done as previously described ${ }^{19}$ using a standard pipeline. Exons 10 and 11 were also sequenced using Sanger sequencing since the coverage of NGS of these exons was low. Table e-2 (github.com/gan-orlab/GBA_RBD/) details the probes used for the MIPs capture. Classification of GBA variants as severe or mild was performed as described 
Table 1 GBA variants in the participating centers

\begin{tabular}{|c|c|c|c|c|c|c|}
\hline \multirow[b]{2}{*}{ Center } & \multirow{2}{*}{$\begin{array}{l}\text { GBA variant carriers, } n \\
(\%) / n \text { total patients with } \\
\text { iRBD }\end{array}$} & \multicolumn{2}{|c|}{ GBA variants identified } & \multirow{2}{*}{$\begin{array}{l}\text { Conversion data } \\
\text { available for } \\
\text { patients, } n\end{array}$} & \multicolumn{2}{|c|}{$\begin{array}{l}\text { Conversion in GBA carriers: } \\
\text { condition (n converted) }\end{array}$} \\
\hline & & Mild & Severe & & Mild & Severe \\
\hline Montreal, Canada & $20(15) / 138$ & $\begin{array}{l}\text { p.N370S-3 } \\
\text { p.E326K-5 } \\
\text { p.T369M-7 } \\
\text { p.W378G-2 }\end{array}$ & $\begin{array}{l}\text { p.L444P-1 } \\
\text { p.H255Q-1 } \\
\text { p.W291X-1 }\end{array}$ & 125 & $\begin{array}{l}\text { p.E326K-DLB (2), PD } \\
\text { (1), dementia (1) } \\
\text { p.T369M-PD (3), } \\
\text { MSA (1), dementia (1) } \\
\text { p.W378G-DLB (2) }\end{array}$ & $\begin{array}{l}\text { p.L444P-PD } \\
\text { (1) } \\
\text { p.H255Q-PD } \\
\text { (1) } \\
\text { p.W291X-PD } \\
\text { (1) }\end{array}$ \\
\hline Innsbruck, Austria & $7(9) / 80$ & p.E326K-7 & & 69 & p.E326K-PD (1) & \\
\hline Bologna, Italy & $2(7) / 28$ & $\begin{array}{l}\text { p.E326K-1 } \\
\text { p.R2L-1 }\end{array}$ & & 19 & - & \\
\hline $\begin{array}{l}\text { Prague, Czech } \\
\text { Republic }\end{array}$ & $3(6) / 47$ & $\begin{array}{l}\text { p.E326K-1 } \\
\text { p.T369M-2 }\end{array}$ & & 46 & $\begin{array}{l}\text { p.T369M-dementia } \\
\text { (1) }\end{array}$ & \\
\hline Paris, France & $14(6) / 219$ & $\begin{array}{l}\text { p.E326K-8 } \\
\text { p.N370S-4 } \\
\text { p.T369M-2 }\end{array}$ & & 77 & $\begin{array}{l}\text { p.E326K-PD (1), } \\
\text { dementia (1) } \\
\text { p.N370S-PD (1) }\end{array}$ & \\
\hline $\begin{array}{l}\text { Montpellier, France } \\
\text { (Beau Soleil Clinic) }\end{array}$ & $5(19) / 26$ & $\begin{array}{l}\text { p.E326K-2 } \\
\text { p.N370S-1 } \\
\text { p.T369M-1 } \\
\text { p.R502C-1 }\end{array}$ & & 2 & p.R502C-PD (1) & \\
\hline Lille, France & $5(22) / 23$ & $\begin{array}{l}\text { p.E326K-2 } \\
\text { p.N370S-2 }\end{array}$ & p.R131L-1 & 15 & $\begin{array}{l}\text { p.N370S-PD (1), } \\
\text { MSA (1) }\end{array}$ & $\begin{array}{l}\text { p.R131L-PD } \\
\text { (1) }\end{array}$ \\
\hline $\begin{array}{l}\text { Montpellier, France } \\
\text { (CHU Montpellier) }\end{array}$ & $8(8) / 96$ & $\begin{array}{l}\text { p.E326K-5 } \\
\text { p.N370S-2 } \\
\text { p.T369M-1 }\end{array}$ & & 14 & p.T369M-DLB (1) & \\
\hline Kessel, Germany & $3(11) / 27$ & $\begin{array}{l}\text { p.E326K-2 } \\
\text { p.T369M-1 }\end{array}$ & & 27 & p.T369M-DLB (1) & \\
\hline Udine, Italy & $6(7) / 83$ & $\begin{array}{l}\text { p.E326K-2 } \\
\text { p.N370S-2 } \\
\text { p.T369M-1 }\end{array}$ & p.D409H-1 & 25 & $\begin{array}{l}\text { p.E326K -unknown } \\
\text { (1) } \\
\text { p.N370S -unknown } \\
\text { (1) }\end{array}$ & $\begin{array}{l}\text { p.D409H } \\
\text {-unknown (1) }\end{array}$ \\
\hline Milan, Italy & $1(5) / 19$ & p.T369M-1 & & 19 & None & \\
\hline $\begin{array}{l}\text { Oxford, United } \\
\text { Kingdom }\end{array}$ & $27(15) / 181$ & $\begin{array}{l}\text { p.E326K-12 } \\
\text { p.N370S-6 } \\
\text { p.N227S-1 } \\
\text { p.T369M-4 } \\
\text { p.T369M/ } \\
\text { p.E326K-1 } \\
\text { p.R2L-1 } \\
\text { p.Y212H-1 }\end{array}$ & $\begin{array}{l}\text { p.D409H } \\
-1\end{array}$ & 97 & $\begin{array}{l}\text { p.E326K-PD (2) } \\
\text { p.N370S -PD (1) }\end{array}$ & \\
\hline
\end{tabular}

Abbreviations: DLB = dementia with Lewy bodies; iRBD = isolated REM sleep behavior disorder; MSA = multiple system atrophy; Parkinson disease. Centers with no GBA variant carriers are excluded from the table: Geel, Belgium ( $n=9)$; Nimes, France $(n=5)$; Marburg, Germany ( $n=29)$; Munster, Germany ( $n$ $=23)$; Cagliari, Italy $(\mathrm{n}=28)$.

previously ${ }^{5,12}$ based on the occurrence of these variants in the severe (type II and type III) and mild (type I) forms of GD. The p.E326K and p.T369M variants, which do not cause GD but have a comparable risk as that of the p.N370S variants in $\mathrm{PD},{ }^{20,21}$ were therefore included in the mild variant group.

\section{Statistical analysis}

To examine the association between GBA variants and risk of iRBD and controls, we performed association tests $\left(\chi^{2}\right.$ or Fisher exact test), logistic regression adjusted for sex and age, and burden tests. To examine the association of GBA variants with risk of $\mathrm{iRBD}$ comparing all controls, we used $\chi^{2}$ or Fisher exact tests since there were no available data on age and sex from the controls collected from the literature to perform adjusted logistic regression. We therefore also performed this association using only our in-house European controls, for which data on age and sex were available, using logistic regression model adjusted for age and sex. Of note, having younger controls may result in underestimation of the risk, as some of the young controls with GBA variants may develop $\mathrm{iRBD}$ or overt neurodegeneration in the future. Therefore, if the statistical adjustment is not complete, the risk estimations that were calculated could be slightly lower (i.e., false-positive results are not likely; rather, underestimated risk is likely). We 
also performed burden tests using the R package SKAT. Association with $A A O$ and specific types of $G B A$ variants (severe or mild) was tested using the nonparametric Kruskal-Wallis test since the group of severe GBA variants included only 5 patients. The association with conversion was tested using a $\chi^{2}$ test for the total number of conversions, and KaplanMeier survival analysis was performed to examine the rate of conversion. All statistical analyses were performed using $\mathrm{R}$ or SPSS v24 (IBM, Armonk, NY).

\section{Standard protocols approvals, registrations, and patient consents}

All study participants signed informed consent forms, and the study protocol was approved by the institutional review boards.

\section{Data availability}

Anonymized data will be shared by request from any qualified investigator.

\section{Results}

GBA variants are associated with increased risk of $i R B D$ with differential effects of severe and mild variants.

The variants in GBA identified in each of the participating centers are detailed in table 1 , with a total of 17 distinct variants found in patients and controls (table 2). Table e-1 details the variants found in each of the previously published control populations. Out of 1,061 patients with iRBD, 101 GBA variant carriers (9.5\%) were identified, compared to 126 out of 3,086 (4.1\%) controls (table 2; odds ratio [OR], 2.45; $95 \%$ confidence interval $\left.[\mathrm{CI}], 1.87-3.22 ; p=1 \times 10^{-10}\right)$. We repeated this analysis using a logistic regression model adjusted for age and sex using the controls with available data ( $\mathrm{n}$ $=1,317$ ), which yielded very similar results (OR, 2.12; 95\% CI, 1.34-3.36; $p=0.001$ ). Burden tests using the $\mathrm{R}$ package SKAT also yielded similar results $\left(p=2.6 \times 10^{-6}\right.$ using the inhouse controls and $p=1.7 \times 10^{-12}$ using all controls). Similar to previous observations in $\mathrm{PD}$, different $G B A$ variants have different effects on the risk of iRBD. The mild p.N370S variant was found in 20 patients with iRBD (1.9\%) compared to $16(0.5 \%)$ controls (OR, 3.69; 95\% CI, 1.90-7.14; $p=3.5 \times$ $10^{-5}$ ), while severe variants (p.L444P, p.D409H, p.W291X, p.H255Q and p.R131L) were found in $6(0.6 \%)$ patients with iRBD and in 1 (p.L444P, $0.03 \%$ ) control (OR, 17.55; 95\% CI, $2.11-145.9 ; p=0.0015)$. Of the 2 polymorphisms known to be risk factors for PD, p.E326K and p.T369M, only p.E326K was associated with iRBD (4.4\% vs $1.5 \%$ in patients and controls; OR, 3.2; 95\% CI, 2.12-4.84; $p=6 \times 10^{-9}$ ), and the carrier frequency of p.T369M was only slightly elevated in iRBD but not statistically significant ( $1.9 \%$ vs $1.7 \%$; OR, 1.13 ; 95\% CI, 0.68-1.89; $p=0.6$ ). The carrier frequencies of the p.N370S, p.E326K, and p.T369M variants in gnomAD (gnomad.broadinstitute.org/) in the European population are $0.4 \%, 2.4 \%$, and $1.9 \%$, respectively, similar to the frequencies in our controls.

\section{Estimated AAO of iRBD may be affected by the type of $G B A$ variant}

AAO as reported by the patients could be an unreliable estimate and data were not available for all patients. Therefore, the following results should be considered with caution. Carriers of the severe GBA variants had an average AAO of $52.8 \pm 2.8$ years (data were available for 5 out of 6 patients with a severe $G B A$ variant), carriers of all other variants had an average AAO of $59.7 \pm 9.6$ years (data were available for 58 patients), and noncarriers of GBA variants had an average AAO of $60.6 \pm 9.9$ years (data were available for 531 patients). Because there were only 5 patients in the severe variants group, the nonparametric Kruskal-Wallis test was performed, demonstrating a possible association with the type of variant $\left(\chi^{2}=7.083, d f=3, p=0.029\right)$, which will benefit from replication in a larger sample size.

\section{Do GBA variants affect the rate of conversion of iRBD to overt neurodegenerative diseases?}

Data on conversion of iRBD was available for 59 GBA variant carriers and 525 noncarriers of GBA variants. Of the GBA variant carriers, 31 (52.5\%) had converted, and in noncarriers $187(35.6 \%)$ had converted $(p=0.011)$. Data on time from iRBD diagnosis to phenoconversion or last follow-up was available for 29 GBA variant carriers and for 276 noncarriers. Kaplan-Meier survival analysis suggested that GBA variant carriers progressed faster but the difference vs noncarriers of $G B A$ variants was not statistically significant (figure). When severe GBA variant carriers were compared to mild GBA carriers and noncarriers, a possible association was demonstrated, as the Breslow test was statistically significant and the Tarone-Ware test was at near statistical significance, while the log-rank test did not reach statistical significance (figure; Breslow $p=0.017$, Tarone-Ware $p=0.051, \log$-rank $p=0.24$ ).

\section{Discussion}

Our results confirm the association between $G B A$ variants and increased risk of $i R B D$ and suggest that severe and mild GBA variants have differential effects on risk, similar to previous reports in PD. ${ }^{5}$ These results also suggest that patients with iRBD with severe GBA variants may have earlier $A A O$ and may convert faster to overt neurodegenerative disease. However, the results on AAO and conversion should be considered as preliminary only and with caution, due to several limitations discussed below.

Three previous small sample size studies have examined the association between GBA variants and iRBD..$^{15,16,22}$ Two of these studies included full sequencing of the gene $\mathrm{e}^{15,16}$ and the third only examined 2 specific variants (p.N370S and p.L444P). ${ }^{22}$ Due to their size, analyses of specific variants or types of variants, such as severe or mild, were not possible. The current study includes 2 of the previously published cohorts $^{15,22}$ and additional cohorts of European ancestry. With the larger sample size accrued, we were able to 
Table 2 GBA variants in patients with isolated REM sleep behavior disorder (iRBD) and controls

\begin{tabular}{|c|c|c|c|c|}
\hline$G B A$ variant $^{a}$ & $\begin{array}{l}\text { Patients with iRBD, } n(\%) \\
(n=1,061)\end{array}$ & $\begin{array}{l}\text { All controls, } n(\%) \\
(n=3,086)\end{array}$ & $\begin{array}{l}\text { In-house controls, } n(\%) \\
(n=1,317)\end{array}$ & $\begin{array}{l}\text { Literature controls, } n(\%) \\
(n=1,769)\end{array}$ \\
\hline \multicolumn{5}{|l|}{ Heterozygous } \\
\hline p.R2L & $2(0.2)$ & $2(0.06)$ & $1(0.08)$ & $1(0.06)$ \\
\hline p.K79M & - & $1(0.03)$ & - & $1(0.06)$ \\
\hline p.R131L & $1(0.1)$ & - & - & - \\
\hline p.Y212H & $1(0.1)$ & - & - & - \\
\hline p.N227S & $1(0.1)$ & - & - & - \\
\hline p.H255Q & $1(0.1)$ & - & - & - \\
\hline p.W291X & $1(0.1)$ & - & - & - \\
\hline p.E326K & $47(4.4)$ & $45(1.4)$ & $18(1.4)$ & $27(1.5)$ \\
\hline р.T369M & $20(1.9)$ & $54(1.7)$ & $35(2.7)$ & $19(1.1)$ \\
\hline p.N370s & $20(1.9)$ & $16(0.5)$ & $10(0.8)$ & $6(0.3)$ \\
\hline p.W378G & $2(0.2)$ & $1(0.03)$ & $1(0.08)$ & - \\
\hline p.E388K & - & $3(0.09)$ & - & $3(0.17)$ \\
\hline p.D409H & $2(0.2)$ & - & - & - \\
\hline p.L444P & $1(0.1)$ & $1(0.03)$ & - & $1(0.06)$ \\
\hline p.V460L & - & $2(0.06)$ & - & $2(0.11)$ \\
\hline p.T482K & - & $1(0.03)$ & - & $1(0.06)$ \\
\hline p.R502C & $1(0.1)$ & - & - & - \\
\hline \multicolumn{5}{|c|}{ Homozygous/compound heterozygous } \\
\hline p.E326K/p.T369M & $1(0.1)$ & - & - & - \\
\hline Total & $101(9.5)$ & $126(4.1)$ & $65(4.9)$ & $61(3.4)$ \\
\hline
\end{tabular}

${ }^{a}$ Variants nomenclature is according to the nomenclature typically used for GBA variants, of the active enzyme (497 amino acids) after the removal of the 39 amino acids of the leader peptide.

demonstrate a much larger risk in carriers of severe GBA variants. Given the small numbers of these variants and the wide range of the CIs, the risk estimates may be different in future, larger studies. The current results are in line with previous results from $\mathrm{PD}$, which clearly demonstrated similar relationships between severe and mild GBA variants and risk for PD. ${ }^{5}$ Previous studies have also suggested that the type of GBA variants may affect PD progression, ${ }^{13,14}$ which is further supported by our preliminary findings on $\mathrm{AAO}$ and conversion of $\mathrm{iRBD}$.

In recent years it has been demonstrated that the coding variants p.E326K and p.T369M, which do not cause GD, are risk factors for $\mathrm{PD} .^{20,21,23}$ In DLB, the association between p.E326K and risk for the disease is clear, yet it is still unclear whether p.T369M is a risk factor for DLB. Only a few studies that examined p.T369M in DLB have been performed and in most of them there was no association. A multicenter study that included over 700 patients with DLB reported lack of association, and in a GWAS with over 1,700 patients with
DLB, only the p.E326K variant was reported to be associated with the disease. ${ }^{7}$ Conversely, recent data from 556 patients with DLB did suggest an association. ${ }^{24}$ The lack of association in the current study in iRBD may also provide further support for lack of association of p.T369M with iRBD and DLB. However, it is important to keep in mind that the association of this variant with PD was only reported in much larger studies ${ }^{20,21}$ due to its lower effect on risk compared to other GBA variants. Only much larger studies can determine conclusively whether p.T369M is associated with $\mathrm{iRBD}$ and DLB. There was a large difference between the frequency of p.T369M in our in-house controls $(2.7 \%)$ and the controls from the literature $(1.1 \%)$, perhaps due to population structure, but the combined frequency $(1.7 \%)$ is comparable to that seen in the gnomAD European population (1.9\%), rendering our results for this variant as likely unbiased.

Our study has several limitations. The possible association between GBA variants and rate of conversion reported here, 
A. Time to conversion (GBA carriers vs wild type)

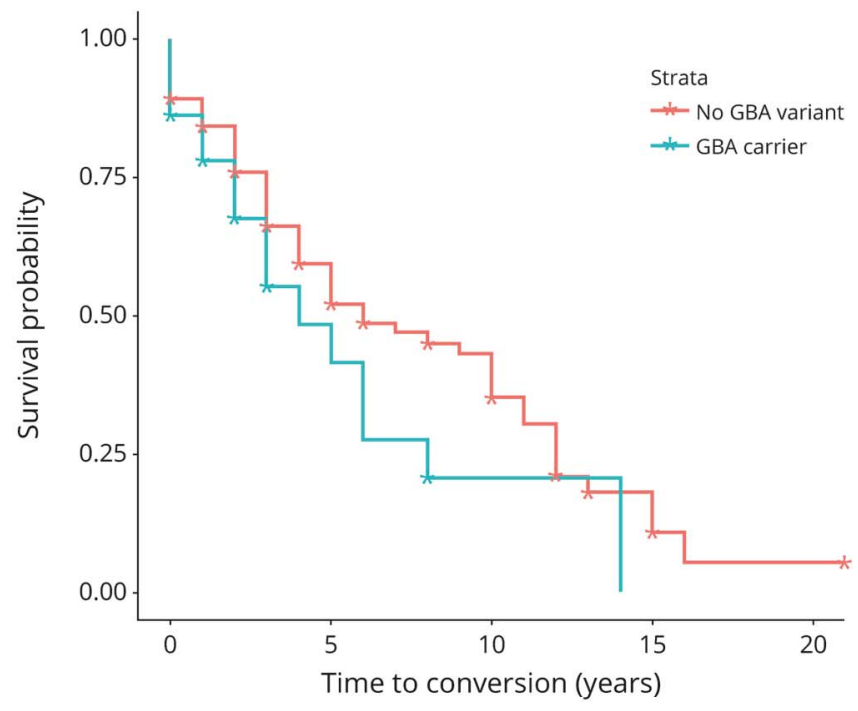

B. Time to conversion (severity of GBA variant)

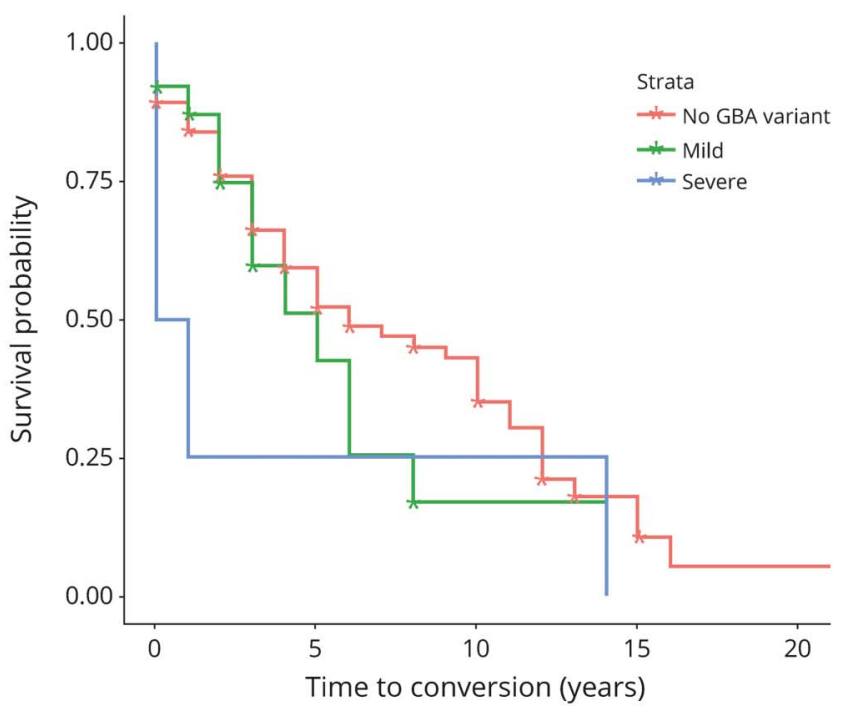

(A) Survival plot comparing GBA variant carriers (blue) and noncarriers (red) from diagnosis until conversion or recent follow-up. Log-rank $p=0.13$, Breslow $p=$ 0.32 , Tarone-Ware $p=0.22$. (B) Survival plot comparing carriers of severe GBA variants (blue), mild/other GBA variants (green), and noncarriers (red). Log-rank $p=0.24$, Breslow $p=0.017$, Tarone-Ware $p=0.051$.

although potentially interesting, should be taken with caution for several reasons. (1) The results include the cohort from Montreal, in which it was previously reported that GBA variants are associated with rate of conversion, but it does not include the negative study from Barcelona (data could not be shared). (2) The results are based on a small number of variant carriers (4 patients with a severe GBA variant, 25 with other $G B A$ variants). Larger studies will be required to determine conclusively whether $G B A$ variants are associated with the rate of phenoconversion. An additional potential limitation is that the measured duration from age at diagnosis or iRBD to conversion might not reflect the actual length of disease duration, as patients can remain unaware for many years about their dreamenactment behaviors, especially if they do not have a bed partner or if they do not have very active or violent dreams. The small number of severe GBA variants is also a limitation in the risk analysis, as it created a wide CI. Since the effect of severe vs mild variants is in line with previous studies in PD, it is likely that these risk estimates of iRBD are overall correct, yet the precise estimate might change in future, larger studies.

The mechanisms underlying the association between $G B A$ variants, the enzyme encoded by GBA, glucocerebrosidase (GCase), and the development of neurodegeneration are unknown. ${ }^{11}$ Several mechanisms have been proposed, including interaction of GCase substrates with $\alpha$-synuclein, which may lead to its accumulation, ${ }^{25}$ changes in the lysosomal membrane composition, which may lead to reduced autophagy and mitophagy, ${ }^{26,27}$ accumulation of misfolded
GCase and endoplasmic reticulum stress, ${ }^{28}$ and others. The association with iRBD may suggest that studying these mechanisms in nondopaminergic neuronal models that are involved in RBD could lead to new discoveries and better understanding of these potential mechanisms.

Our results demonstrate that GBA variants are associated with increased risk of iRBD. These results may also suggest that severe and mild GBA variants may have differential effects on the risk, and possibly on AAO, of $\mathrm{iRBD}$ and its conversion to overt neurodegenerative disease. Due to the limitations mentioned above, the latter associations should be considered as preliminary with additional, larger studies on GBA in iRBD required to confirm or refute them. One important implication of the association between GBA variants and $\mathrm{iRBD}$ is the possibility to perform screening for iRBD in healthy GBA variant carriers. This may allow for even earlier detection of prodromal neurodegeneration and could be especially useful when home detection of iRBD will be made possible.

\section{Acknowledgment}

The authors thank the patients and controls for participation and Helene Catoire, Sandra B. Laurent, and Dan Spiegelman for assistance. J.-F.G. holds a Canada Research Chair in Cognitive Decline in Pathological Aging. W.O. is Hertie Senior Research Professor, supported by the Charitable Hertie Foundation, Frankfurt/Main, Germany. G.A.R. holds a Canada Research Chair in Genetics of the Nervous System and the Wilder Penfield Chair in Neurosciences. Z.G.-O. is supported by the Fonds de Recherche du Québec-Santé (FRQS) Chercheurs-Boursiers Award given in collaboration 
with Parkinson QC, and is a Parkinson Canada New Investigator awardee.

\section{Study funding}

This work was supported financially by Parkinson Canada, the Michael J. Fox Foundation, the Canadian Consortium on Neurodegeneration in Aging (CCNA), the Canadian Glycomics Network (GlycoNet), the Canada First Research Excellence Fund (CFREF), awarded to McGill University for the Healthy Brains for Healthy Lives (HBHL) program, the Canadian Institutes for Health Research (CIHR), Weston Foundation, and Fonds de Recherche du Québec-Santé (FRQS) Chercheurs-Boursiers. The Oxford Discovery study is funded by the Monument Trust Discovery Award from Parkinson's UK and supported by the National Institute for Health Research (NIHR) Oxford Biomedical Research Centre based at Oxford University Hospitals NHS Trust and University of Oxford, the NIHR Clinical Research Network, and the Dementias and Neurodegenerative Diseases Research Network (DeNDRoN).

\section{Disclosure}

L. Krohn, J. Ruskey, U. Rudakou, E. Leveille, and F. Asayesh report no disclosures relevant to the manuscript. M. Hu received consultancy fees from Roche and Biogen Pharmaceuticals. I. Arnulf received fees for speaking engagements from UCB Pharma and consultancy for Roche, Novartis, and Ono Pharma. Y. Dauvilliers reports no disclosures relevant to the manuscript. B. Högl received consultancy fees from Axovant, benevolent Bio, Takeda, Roche, and Ono Pharma, and received speaker honoraria from Eli Lilly, Mundipharma, UCB, AbbVie, Inspire, and Lundbeck. A. Stefani, C. Monaca, B. Abril, G. Plazzi, E. Antelmi, and L. Ferini-Strambi report no disclosures relevant to the manuscript. A. Heidbreder received honoraria for lectures from UCB, Bioprojet, Servier, and Medice and consultancy fees from UCB. B. Boeve has served as an investigator for clinical trials sponsored by Biogen and Alector; serves on the Scientific Advisory Board of the Tau Consortium; and receives research support from the NIH, the Mayo Clinic Dorothy and Harry T. Mangurian Jr. Lewy Body Dementia Program, the Little Family Foundation, and the LBD Functional Genomics Program. A.J. Espay received grant support from the NIH and the Michael J. Fox Foundation; personal compensation as a consultant/scientific advisory board member for AbbVie, Adamas, Acadia, Acorda, Neuroderm, Neurocrine, Impax/Amneal, Sunovion, Lundbeck, Osmotica Pharmaceutical, and USWorldMeds; publishing royalties from Lippincott Williams \& Wilkins, Cambridge University Press, and Springer; and honoraria from USWorldMeds, Lundbeck, Acadia, Sunovion, the American Academy of Neurology, and the Movement Disorders Society. V. Cochen De Cock reports no disclosures relevant to the manuscript. B. Mollenhauer has received honoraria for consultancy from Roche, Biogen, UCB, and Sun Pharma Advanced Research Company; is a member of the executive steering committee of the Parkinson Progression Marker Initiative and PI of the Systemic Synuclein Sampling
Study of the Michael J. Fox Foundation for Parkinson's Research; and has received research funding from the Deutsche Forschungsgemeinschaft (DFG), EU (Horizon2020), Parkinson Fonds Deutschland, Deutsche Parkinson Vereinigung, and the Michael J. Fox Foundation for Parkinson's Research. F. Sixel-Döring has received honoraria for lectures from Abbott, Desitin, Grünenthal, Licher MT, STADA Pharm, and UCB; seminar fees from Boston Scientific and Licher MT; serves on an advisory board for STADA Pharm; and reports no conflict of interest with the presented study. C. Trenkwalder has received honoraria for lectures from UCB, Grünenthal, and Otsuka and consultancy fees from Britannia Pharmaceuticals and Roche. K. Sonka, D. Kemlink, M. Figorilli, M. Puligheddu, F. Dijkstra, and M. Viaene report no disclosures relevant to the manuscript. W. Oertel received consultancy or speaker fees from Adamas, AbbVie, Desitin, Novartis and Roche, and reports no conflicts of interest related to the study. M. Toffoli, G. Luigi Gigli, and M. Valente report no disclosures relevant to the manuscript. J.F. Gagnon reports research funding from the Canadian Institutes for Health Research (CIHR). A. Desautels received grants from Flamel Ireland, Pfized, Biron, and Canopy Growth, as well as fees for speaking engagements from Biogen and consultancy from UCB Pharma. J. Montplaisir reports no disclosures relevant to the manuscript. $\mathrm{R}$. Postuma reports grants from Fonds de la Recherche en Sante, the Canadian Institute of Health Research, The Parkinson Society of Canada, the Weston-Garfield Foundation, the Michael J. Fox Foundation, and the Webster Foundation, as well as personal fees from Takeda, Roche, Teva Neurosciences, Novartis Canada, Biogen, Boehringer Ingelheim, Theranexus, GE HealthCare, Jazz Pharmaceuticals, AbbVie, Jannsen, Otsuko, Phytopharmics, and Inception Sciences. G. Rouleau reports no disclosures relevant to the manuscript. Z. Gan-Or received consultancy fees from Lysosomal Therapeutics Inc. (LTI), Idorsia, Prevail Therapeutics, Inceptions Sciences (now Ventus), Denali, and Deerfield. Go to Neurology.org/N for full disclosures.

\section{Publication history}

Received by Neurology October 30, 2019. Accepted in final form February 14, 2020.

Appendix Authors

\begin{tabular}{lll}
\hline Name & Location & Contribution \\
\hline $\begin{array}{l}\text { Lynne Krohn, } \\
\text { MSc }\end{array}$ & $\begin{array}{l}\text { McGill University, } \\
\text { Montréal, Canada }\end{array}$ & $\begin{array}{l}\text { Designed and } \\
\text { conceptualized study, } \\
\text { analyzed the data, drafted } \\
\text { the manuscript for } \\
\text { intellectual content }\end{array}$ \\
\hline $\begin{array}{l}\text { Jennifer A. } \\
\text { Ruskey, MSc }\end{array}$ & Monill University, & $\begin{array}{l}\text { Major role in the acquisition } \\
\text { of data, revised the } \\
\text { manuscript for intellectual } \\
\text { content }\end{array}$ \\
\hline $\begin{array}{l}\text { Uladislau } \\
\text { Rudakou, BSc }\end{array}$ & McGill University, & $\begin{array}{l}\text { Analyzed the data, revised } \\
\text { the manuscript for } \\
\text { intellectual content }\end{array}$ \\
\hline
\end{tabular}


Appendix (continued)

\begin{tabular}{|c|c|c|}
\hline Name & Location & Contribution \\
\hline $\begin{array}{l}\text { Etienne } \\
\text { Leveille }\end{array}$ & $\begin{array}{l}\text { McGill University, } \\
\text { Montréal, Canada }\end{array}$ & $\begin{array}{l}\text { Interpreted the data, } \\
\text { revised the manuscript for } \\
\text { intellectual content }\end{array}$ \\
\hline $\begin{array}{l}\text { Farnaz } \\
\text { Asayesh, MSc }\end{array}$ & $\begin{array}{l}\text { McGill University, } \\
\text { Montréal, Canada }\end{array}$ & $\begin{array}{l}\text { Major role in the acquisition of } \\
\text { data, revised the manuscript } \\
\text { for intellectual content }\end{array}$ \\
\hline $\begin{array}{l}\text { Michele T.M. } \\
\text { Hu, MBBS, } \\
\text { FRCP, PhD }\end{array}$ & Oxford University, UK & $\begin{array}{l}\text { Major role in the acquisition of } \\
\text { data, revised the manuscript } \\
\text { for intellectual content }\end{array}$ \\
\hline $\begin{array}{l}\text { Isabelle } \\
\text { Arnulf, MD, } \\
\text { PhD }\end{array}$ & $\begin{array}{l}\text { Moelle Epinière and } \\
\text { Sorbonne Universities, } \\
\text { Paris, France }\end{array}$ & $\begin{array}{l}\text { Major role in the acquisition } \\
\text { of data, revised the } \\
\text { manuscript for intellectual } \\
\text { content }\end{array}$ \\
\hline $\begin{array}{l}\text { Yves } \\
\text { Dauvilliers, } \\
\text { MD, PhD }\end{array}$ & $\begin{array}{l}\text { CHU Montpellier, } \\
\text { France }\end{array}$ & $\begin{array}{l}\text { Major role in the acquisition } \\
\text { of data, revised the } \\
\text { manuscript for intellectual } \\
\text { content }\end{array}$ \\
\hline Birgit Högl, MD & $\begin{array}{l}\text { Medical University of } \\
\text { Innsbruck, Austria }\end{array}$ & $\begin{array}{l}\text { Major role in the acquisition } \\
\text { of data, revised the } \\
\text { manuscript for intellectual } \\
\text { content }\end{array}$ \\
\hline $\begin{array}{l}\text { Ambra Stefani, } \\
\text { MD }\end{array}$ & $\begin{array}{l}\text { Medical University of } \\
\text { Innsbruck, Austria }\end{array}$ & $\begin{array}{l}\text { Major role in the acquisition } \\
\text { of data, revised the } \\
\text { manuscript for intellectual } \\
\text { content }\end{array}$ \\
\hline $\begin{array}{l}\text { Christelle } \\
\text { Charley } \\
\text { Monaca, MD, } \\
\text { PhD }\end{array}$ & CHU Lille, France & $\begin{array}{l}\text { Major role in the acquisition } \\
\text { of data, revised the } \\
\text { manuscript for intellectual } \\
\text { content }\end{array}$ \\
\hline $\begin{array}{l}\text { Beatriz Abril, } \\
\text { MD }\end{array}$ & $\begin{array}{l}\text { University Hospital of } \\
\text { Nîmes, France }\end{array}$ & $\begin{array}{l}\text { Major role in the acquisition } \\
\text { of data, revised the } \\
\text { manuscript for intellectual } \\
\text { content }\end{array}$ \\
\hline $\begin{array}{l}\text { Giuseppe } \\
\text { Plazzi, MD }\end{array}$ & $\begin{array}{l}\text { University of Bologna, } \\
\text { Italy }\end{array}$ & $\begin{array}{l}\text { Major role in the acquisition } \\
\text { of data, revised the } \\
\text { manuscript for intellectual } \\
\text { content }\end{array}$ \\
\hline $\begin{array}{l}\text { Elena Antelmi, } \\
\text { MD, PhD }\end{array}$ & $\begin{array}{l}\text { University of Bologna, } \\
\text { Italy }\end{array}$ & $\begin{array}{l}\text { Major role in the acquisition } \\
\text { of data, revised the } \\
\text { manuscript for intellectual } \\
\text { content }\end{array}$ \\
\hline $\begin{array}{l}\text { Luigi Ferini- } \\
\text { Strambi, MD }\end{array}$ & $\begin{array}{l}\text { Università Vita-Salute } \\
\text { San Raffaele, Milan, } \\
\text { Italy }\end{array}$ & $\begin{array}{l}\text { Major role in the acquisition } \\
\text { of data, revised the } \\
\text { manuscript for intellectual } \\
\text { content }\end{array}$ \\
\hline $\begin{array}{l}\text { Anna } \\
\text { Heidbreder, } \\
\text { MD }\end{array}$ & $\begin{array}{l}\text { University of Muenster, } \\
\text { Germany }\end{array}$ & $\begin{array}{l}\text { Major role in the acquisition } \\
\text { of data, revised the } \\
\text { manuscript for intellectual } \\
\text { content }\end{array}$ \\
\hline $\begin{array}{l}\text { Bradley F. } \\
\text { Boeve, MD }\end{array}$ & $\begin{array}{l}\text { Mayo Clinic, Rochester, } \\
\text { MN }\end{array}$ & $\begin{array}{l}\text { Major role in the acquisition } \\
\text { of data, revised the } \\
\text { manuscript for intellectual } \\
\text { content }\end{array}$ \\
\hline $\begin{array}{l}\text { Alberto J. } \\
\text { Espay, MD, } \\
\text { MSc }\end{array}$ & $\begin{array}{l}\text { UC Gardner } \\
\text { Neuroscience Institute, } \\
\text { Cincinnati, } \mathrm{OH}\end{array}$ & $\begin{array}{l}\text { Major role in the acquisition } \\
\text { of data, revised the } \\
\text { manuscript for intellectual } \\
\text { content }\end{array}$ \\
\hline $\begin{array}{l}\text { Valérie Cochen } \\
\text { De Cock, MD, } \\
\text { PhD }\end{array}$ & $\begin{array}{l}\text { Beau Soleil Clinic, } \\
\text { Montpellier, France }\end{array}$ & $\begin{array}{l}\text { Major role in the acquisition } \\
\text { of data, revised the } \\
\text { manuscript for intellectual } \\
\text { content }\end{array}$ \\
\hline
\end{tabular}

Appendix (continued)

\begin{tabular}{|c|c|c|}
\hline Name & Location & Contribution \\
\hline $\begin{array}{l}\text { Brit } \\
\text { Mollenhauer, } \\
\text { MD }\end{array}$ & $\begin{array}{l}\text { University Medical } \\
\text { Centre Goettingen, } \\
\text { Germany }\end{array}$ & $\begin{array}{l}\text { Major role in the acquisition of } \\
\text { data, revised the manuscript } \\
\text { for intellectual content }\end{array}$ \\
\hline $\begin{array}{l}\text { Friederike } \\
\text { Sixel-Döring, } \\
\text { MD }\end{array}$ & $\begin{array}{l}\text { Philipps University, } \\
\text { Marburg, Germany }\end{array}$ & $\begin{array}{l}\text { Major role in the acquisition of } \\
\text { data, revised the manuscript } \\
\text { for intellectual content }\end{array}$ \\
\hline $\begin{array}{l}\text { Claudia } \\
\text { Trenkwalder, } \\
\text { MD }\end{array}$ & $\begin{array}{l}\text { University Medical } \\
\text { Centre Goettingen, } \\
\text { Germany }\end{array}$ & $\begin{array}{l}\text { Major role in the acquisition of } \\
\text { data, revised the manuscript } \\
\text { for intellectual content }\end{array}$ \\
\hline $\begin{array}{l}\text { Karel Sonka, } \\
\text { MD }\end{array}$ & $\begin{array}{l}\text { Charles University, } \\
\text { Prague, Czech Republic }\end{array}$ & $\begin{array}{l}\text { Major role in the acquisition } \\
\text { of data, revised the } \\
\text { manuscript for intellectual } \\
\text { content }\end{array}$ \\
\hline
\end{tabular}

David Kemlink, Charles University,

Major role in the acquisition MD, PhD Prague, Czech Republic of data, revised the manuscript for intellectual content

\begin{tabular}{lll}
\hline Michela & University of Cagliari, & Major role in the acquisition \\
Figorilli, MD, & Italy & $\begin{array}{l}\text { of data, revised the } \\
\text { manuscript for intellectual } \\
\text { PhD }\end{array}$ \\
& \\
& content
\end{tabular}

\begin{tabular}{lll}
\hline $\begin{array}{l}\text { Monica } \\
\text { Puligheddu, }\end{array}$ & University of Cagliari, & $\begin{array}{l}\text { Major role in the acquisition } \\
\text { of data, revised the } \\
\text { MD, PhD }\end{array}$ \\
& & $\begin{array}{l}\text { manuscript for intellectual } \\
\text { content }\end{array}$
\end{tabular}

Femke St. Dimpna Regional Major role in the acquisition

Dijkstra, MD Hospital, Geel, Belgium of data, revised the manuscript for intellectual content

\begin{tabular}{lll}
\hline $\begin{array}{l}\text { Mineke } \\
\text { Viaene, MD, }\end{array}$ & St. Dimpna Regional & Major role in the acquisition \\
PhD & Hospital, Geel, Belgium & $\begin{array}{l}\text { of data, revised the } \\
\text { manuscript for intellectual } \\
\text { content }\end{array}$
\end{tabular}

\begin{tabular}{lll}
\hline Wolfgang & Philipps University, & Major role in the acquisition \\
Oertel, MD & Marburg, Germany & $\begin{array}{l}\text { of data, revised the } \\
\text { manuscript for intellectual } \\
\text { content }\end{array}$
\end{tabular}

\begin{tabular}{lll}
\hline Marco Toffoli, & University of Udine, \\
Italy & & $\begin{array}{l}\text { Major role in the acquisition } \\
\text { of data, revised the } \\
\text { manuscript for intellectual } \\
\text { content }\end{array}$
\end{tabular}

\begin{tabular}{lll}
\hline Gian Luigi & University Hospital of & $\begin{array}{l}\text { Major role in the acquisition } \\
\text { of data, revised the } \\
\text { Gigli, MD }\end{array}$ \\
Udine, Italy & $\begin{array}{l}\text { mancript for intellectual } \\
\text { content }\end{array}$
\end{tabular}

\begin{tabular}{lll}
\hline $\begin{array}{l}\text { Mariarosaria } \\
\text { Valente, MD }\end{array}$ & University Hospital of & $\begin{array}{l}\text { Major role in the acquisition } \\
\text { of data, revised the } \\
\text { manuscript for intellectual } \\
\text { content }\end{array}$ \\
& &
\end{tabular}

Jean-François Université du Québec à Major role in the acquisition
Gagnon, PhD Montréal, Canada of data, revised the manuscript for intellectual content

\begin{tabular}{lll}
\hline $\begin{array}{l}\text { Alex } \\
\text { Desautels, MD, } \\
\text { PhD }\end{array}$ & $\begin{array}{l}\text { Université de Montréal, } \\
\text { Canada }\end{array}$ & $\begin{array}{l}\text { Major role in the acquisition } \\
\text { of data, revised the } \\
\text { manuscript for intellectual } \\
\text { content }\end{array}$ \\
\hline $\begin{array}{l}\text { Jacques Y. } \\
\text { Montplaisir, } \\
\text { MD, PhD }\end{array}$ & $\begin{array}{l}\text { Université de Montréal, } \\
\text { Canada }\end{array}$ & $\begin{array}{l}\text { Major role in the acquisition } \\
\text { of data, revised the } \\
\text { manuscript for intellectual } \\
\text { content }\end{array}$ \\
\hline
\end{tabular}

Continued 
Appendix (continued)

\begin{tabular}{lll}
\hline Name & Location & Contribution \\
\hline $\begin{array}{l}\text { Ronald B. } \\
\text { Postuma, MD, } \\
\text { MSc }\end{array}$ & $\begin{array}{l}\text { McGill University, } \\
\text { Montréal, Canada }\end{array}$ & $\begin{array}{l}\text { Major role in the acquisition } \\
\text { of data, revised the } \\
\text { manuscript for intellectual } \\
\text { content }\end{array}$ \\
\hline $\begin{array}{l}\text { Guy A. Rouleau } \\
\text { MD, PhD, } \\
\text { FRCPC }\end{array}$ & McGill University, & $\begin{array}{l}\text { Major role in the acquisition } \\
\text { of data, revised the } \\
\text { manuscript for intellectual } \\
\text { content }\end{array}$ \\
\hline $\begin{array}{l}\text { Ziv Gan-Or, } \\
\text { MD, PhD }\end{array}$ & McGill University, & $\begin{array}{l}\text { Designed and } \\
\text { conceptualized study, } \\
\text { major role in the acquisition } \\
\text { of data, drafted the } \\
\text { manuscript for intellectual }\end{array}$ \\
& Montréal, Canada & content \\
\hline
\end{tabular}

\section{References}

1. Hogl B, Stefani A, Videnovic A. Idiopathic REM sleep behaviour disorder and neurodegeneration: an update. Nat Rev Neurol 2018;14:40-55.

2. Postuma RB, Iranzo A, Hu M, et al. Risk and predictors of dementia and parkinsonism in idiopathic REM sleep behaviour disorder: a multicentre study. Brain 2019;142: 744-759.

3. Yao C, Fereshtehnejad SM, Dawson BK, et al. Longstanding disease-free survival in idiopathic REM sleep behavior disorder: is neurodegeneration inevitable? Parkinsonism Relat Disord 2018;54:99-102.

4. Iranzo A, Stefani A, Serradell M, et al. Characterization of patients with longstanding idiopathic REM sleep behavior disorder. Neurology 2017;89:242-248.

5. Gan-Or Z, Amshalom I, Kilarski LL, et al. Differential effects of severe vs mild GBA mutations on Parkinson disease. Neurology 2015;84:880-887.

6. Sidransky E, Nalls MA, Aasly JO, et al. Multicenter analysis of glucocerebrosidase mutations in Parkinson's disease. N Engl J Med 2009;361:1651-1661.

7. Nalls MA, Duran R, Lopez G, et al. A multicenter study of glucocerebrosidase mutations in dementia with Lewy bodies. JAMA Neurol 2013;70:727-735.

8. Mitsui J, Matsukawa T, Sasaki H, et al. Variants associated with Gaucher disease in multiple system atrophy. Ann Clin Transl Neurol 2015;2:417-426.

9. Sailer A, Scholz SW, Nalls MA, et al. A genome-wide association study in multiple system atrophy. Neurology 2016;87:1591-1598.
10. Sklerov M, Kang UJ, Liong C, et al. Frequency of GBA variants in autopsy-proven multiple system atrophy. Mov Disord Clin Pract 2017;4:574-581.

11. Gan-Or Z, Liong C, Alcalay RN. GBA-associated Parkinson's disease and other synucleinopathies. Curr Neurol Neurosci Rep 2018;18:44.

12. Beutler E, Gelbart T, Scott CR. Hematologically important mutations: Gaucher disease. Blood Cell Mol Dis 2005;35:355-364.

13. Cilia R, Tunesi S, Marotta G, et al. Survival and dementia in GBA-associated Parkinson's disease: the mutation matters. Ann Neurol 2016;80:662-673.

14. Liu G, Boot B, Locascio JJ, et al. Specifically neuropathic Gaucher's mutations accelerate cognitive decline in Parkinson's. Ann Neurol 2016;80:674-685.

15. Gan-Or Z, Mirelman A, Postuma RB, et al. GBA mutations are associated with rapid eye movement sleep behavior disorder. Ann Clin Transl Neurol 2015;2:941-945.

16. Gamez-Valero A, Iranzo A, Serradell M, et al. Glucocerebrosidase gene variants are accumulated in idiopathic REM sleep behavior disorder. Parkinsonism Relat Disord 2018;50:94-98

17. Honeycutt L, Montplaisir JY, Gagnon JF, et al. Glucocerebrosidase mutations and phenoconversion of REM sleep behavior disorder to parkinsonism and dementia. Parkinsonism Relat Disord 2019;65:230-233.

18. Hogl B, Stefani A. REM sleep behavior disorder (RBD): update on diagnosis and treatment. Somnologie 2017;21:1-8.

19. Ruskey JA, Zhou S, Santiago R, et al. The GBA p.Trp378Gly mutation is a probable French-Canadian founder mutation causing Gaucher disease and synucleinopathies. Clin Genet 2018;94:339-345.

20. Blauwendraat C, Bras JM, Nalls MA, et al. Coding variation in GBA explains the majority of the SYT11-GBA Parkinson's disease GWAS locus. Mov Disord 2018;33: $1821-1823$.

21. Mallett V, Ross JP, Alcalay RN, et al. GBA p.T369M substitution in Parkinson disease: polymorphism or association? A meta-analysis. Neurol Genet 2016;2:e104.

22. Barber TR, Lawton M, Rolinski M, et al. Prodromal parkinsonism and neurodegenerative risk stratification in REM sleep behavior disorder. Sleep 2017;40.

23. Berge-Seidl V, Pihlstrom L, Maple-Grodem J, et al. The GBA variant E326K is associated with Parkinson's disease and explains a genome-wide association signal. Neurosci Lett 2017;658:48-52.

24. Gan-Or Z, Alcalay RN, Makarious MB, et al. Classification of GBA variants and their effects in synucleinopathies. Mov Disord 2019;34:1581-1582.

25. Mazzulli JR, Xu YH, Sun Y, et al. Gaucher disease glucocerebrosidase and alphasynuclein form a bidirectional pathogenic loop in synucleinopathies. Cell 2011;146: $37-52$.

26. Gan-Or Z, Dion PA, Rouleau GA. Genetic perspective on the role of the autophagylysosome pathway in Parkinson disease. Autophagy 2015;11:1443-1457.

27. Osellame LD, Duchen MR. Defective quality control mechanisms and accumulation of damaged mitochondria link Gaucher and Parkinson diseases. Autophagy 2013;9: 1633-1635.

28. Ron I, Rapaport D, Horowitz M. Interaction between parkin and mutant glucocerebrosidase variants: a possible link between Parkinson disease and Gaucher disease Hum Mol Genet 2010;19:3771-3781. 


\section{Neurology}

\section{$G B A$ variants in REM sleep behavior disorder: A multicenter study \\ Lynne Krohn, Jennifer A. Ruskey, Uladzislau Rudakou, et al.}

Neurology 2020;95; e1008-e1016 Published Online before print June 26, 2020

DOI 10.1212/WNL.0000000000010042

This information is current as of June 26, 2020

\section{Updated Information \& Services}

References

Citations

Subspecialty Collections

Permissions \& Licensing

Reprints including high resolution figures, can be found at: http://n.neurology.org/content/95/8/e1008.full

This article cites 27 articles, 3 of which you can access for free at: http://n.neurology.org/content/95/8/e1008.full\#ref-list-1

This article has been cited by 3 HighWire-hosted articles: http://n.neurology.org/content/95/8/e1008.full\#\#otherarticles

This article, along with others on similar topics, appears in the following collection(s):

Dementia with Lewy bodies

http://n.neurology.org/cgi/collection/dementia_with_lewy_bodies

Parkinson's disease/Parkinsonism

http://n.neurology.org/cgi/collection/parkinsons_disease_parkinsonism

Information about reproducing this article in parts (figures,tables) or in its entirety can be found online at:

http://www.neurology.org/about/about_the_journal\#permissions

Information about ordering reprints can be found online:

http://n.neurology.org/subscribers/advertise

Neurology ${ }^{\circledR}$ is the official journal of the American Academy of Neurology. Published continuously since 1951 , it is now a weekly with 48 issues per year. Copyright Copyright (C) 2020 The Author(s). Published by Wolters Kluwer Health, Inc. on behalf of the American Academy of Neurology.. All rights reserved. Print ISSN: 0028-3878. Online ISSN: 1526-632X.

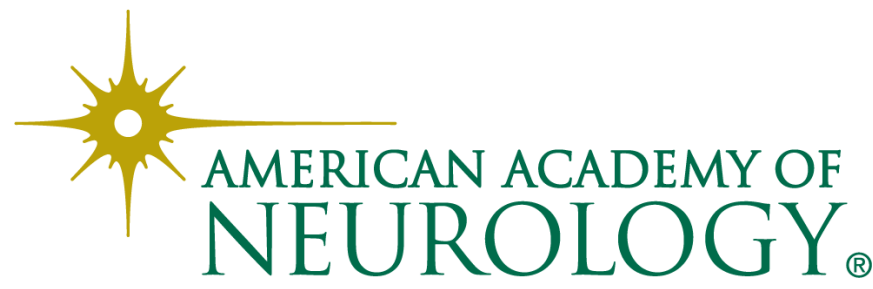

